\title{
Make a Match Techniques in Cooperative Learning: Innovations to Improve Student Learning Outcomes, Student Learning Activities, and Teacher Performance
}

\author{
Viyayanti ${ }^{1}{ }^{*}$ Dwikoranto ${ }^{2}$ \\ 1SMK Negeri 1 Cerme Gresik, Indonesia \\ 2Department of Physics, Faculty of Mathematics and Natural Science, Universitas Negeri Surabaya, Surabaya 60231, \\ Indonesia
}

\begin{abstract}
Article Info
Article history:

Received August 15, 2021

Revised September 1, 2021

Accepted September 8, 2021

Available Online September 9, 2021

Keywords:

Activities

Cooperative learning

Learning outcomes

Make a match

Teacher performance

ABSTRACT

The purpose of this study is to describe improving student learning outcomes, describe student activities, describe teacher performance after applying the make a match technique in cooperative learning. This learning improvement is carried out by classroom action research, with steps of planning, implementing, observing, revising. The research subjects were 34 students in the chemistry class of Vocational School 1 Cerme Gresik. Data were analyzed descriptively quantitatively. The results of the class average score before the action were 70. Students who scored above the Minimum Completeness Criteria (MCC) 76 were 16 students (47\%) with the highest score of 92 and students who scored below the MCC were 18 students $(53 \%)$ with the lowest score of 40 . After taking action in cycle 1 the average grade of 79. Students who scored above or equal to the MCC were 26 students $(76 \%)$ with the highest score of 100 and students who scored below the MCC were 8 students (24\%) with the lowest score of 52 . Cycle 2 the average grade of 84 . Students who scored above the MCC were 31 students $(91 \%)$ with the highest score of 100, while students who scored below the MCC as many as 3 students (9\%) with the lowest score of 64 . The students' attention, activity, and enthusiasm for learning increased. Teacher performance in learning has increased.
\end{abstract}

\section{INTRODUCTION}

The success of learning is determined by many factors, one of which is the teacher's factor in carrying out the teaching and learning process, because the teacher can directly influence, color, foster, and improve student learning outcomes and skills. The role of the teacher remains very important and it is hoped that the teacher has good techniques, strategies, or teaching models and can choose the right learning model and in accordance with the characteristics of the subjects to be delivered (Arends, 2018).

To improve the quality of learning, teachers need to understand the components that affect student learning processes, both those that hinder and support them. In addition, teachers must understand effective learning models, techniques, and strategies that can help students learn optimally and be able to increase student activity in the learning process (Isjoni, 2016). There are various types of learning models, each of which has advantages and disadvantages, so the selection of models with certain techniques that are suitable with the topic or subject to be taught must be considered by the teacher who will deliver the learning material. Every student 
entering the first course in physics subject has a belief system and intuition about physical phenomena that originate from extensive personal experience (Lin et al., 2015).

The results of initial observations made by researchers on chemistry learning carried out in class X KI 2 Vocational School 1 Cerme Gresik which were carried out with lectures, questions, and answers, and assignments showed that student learning activities were still lacking, some students became bored in learning. This is thought to have caused the not yet optimal understanding of the concept of learning material which has an impact on learning outcomes that are still below the Minimum Completeness Criteria (MCC) (Dirmenjur, 2018). Table 1 shows the real conditions obtained where the average value of conceptual understanding is 70 .

Table 1. Students' Initial Value Data Before Action

\begin{tabular}{llll}
\hline No. & Value Interval & Frequency & Percentage \\
\hline $\mathbf{1}$ & $36-45$ & 1 & $3 \%$ \\
$\mathbf{2}$ & $46-55$ & 3 & $9 \%$ \\
$\mathbf{3}$ & $56-65$ & 10 & $29 \%$ \\
$\mathbf{4}$ & $66-75$ & 4 & $12 \%$ \\
$\mathbf{5}$ & $76-84$ & 12 & $35 \%$ \\
$\mathbf{6}$ & $85-100$ & 4 & $12 \%$ \\
\hline Sum & 34 & $100 \%$ \\
Classical completeness & $47 \%$ & \\
Lowest Value & 40 & \\
The highest score & 92 & \\
Average Value & 70 & \\
Students finish studying & $16(47 \%)$ & \\
Students do not finish & $18(53 \%)$ & \\
studying & & \\
\hline
\end{tabular}

Based on Table 1, students who scored below the MCC (76) were 18 students or 53\%, and students who scored the same as or above the MCC were 16 students or $47 \%$. This can be interpreted that classical completeness of $47 \%$ is still below the specified learning mastery of $85 \%$ with students getting a score of 76 , in other words, student learning outcomes are still low.

The low value of learning outcomes or incompleteness is caused by the low understanding of concepts by students. In addition, there are several factors causing students' low understanding of concepts, including: (1) The subject matter that must be completed is very large which confuses students to understand, thus making students regard it as a scourge; (2) Teachers in conducting learning are still conventional, meaning that teachers have not used innovative learning models and interactions that can attract students' interest and activity to learn. (3) Teacher performance is not optimal.

Therefore we need a learning innovation that can improve learning outcomes. by applying the cooperative learning model of the make a match technique. Learning outcomes are the most important part of learning which is essentially a change in behavior covering the cognitive, affective, and psychomotor fields (Sudjana, 2016). Learning outcomes are the result of an interaction between the act of learning and the act of teaching. The teaching act ends with the process of evaluating learning outcomes (Dimyati and Mudjiono, 2016).

The problems to be solved: 1). Learning outcomes still need to be improved through the application of the cooperative learning model of the make a match technique. 2). The low activity of students in the learning process in class. 3). Teacher performance in the classroom is not optimal. While the research objectives: 1). Describe improving learning outcomes. 2). Describe student activities. 3). Describe the teacher's performance.

Cooperative learning model is a learning model that requires the active involvement of students to work together in heterogeneous groups with learning success determined by working together with groups, the purpose of forming groups in cooperative learning models is 
to provide opportunities for all students to be actively involved. active in the process of thinking and learning activities. (Lie, 2015; Isjoni, 2016; Rusman, 2016; Trianto, 2011). This learning model is centered on students to further activate students and to be able to learn and interact with their friends, develop attitudes, values, and behaviors that allow them to participate in learning (Ardana, 2013).

The advantages of cooperative learning can improve students' cognitive and affective skills. In addition, cooperative learning also provides benefits: (1) Increasing social sensitivity and solidarity; (2) enabling students to learn from each other about attitudes, skills, information, social behavior, and views; (3) make it easier for students to make social adjustments; (4) enabling the formation and development of social values and commitments; (5) eliminate selfishness or selfishness; (6) build friendships that can continue into adulthood; (7) the various social skills needed to maintain mutually beneficial relationships can be taught and practiced; (8) increase mutual trust in humans; (9) improve the ability to view problems and situations from various perspectives; (10) increasing willingness to use other people's ideas that they feel are better; (11) increasing fondness for making friends regardless of differences in ability, gender, normal or disabled, ethnicity, social class, religion and task orientation (Sugiyanto, 2014; Slavin, 2013).

There are 14 cooperative learning techniques that are often applied in the classroom. The fourteen techniques are: (1) Make a match; (2) Exchange of Partners; (3) Think-Pair-Share); (4) Sending Greetings and Questions; (5) Numbered Heads Together; (6) Structured Numbered Heads; (7) Two Stay Two Stray; (8) Group Tour; (9) Rattling Buttons; (10) Class circumference; (11) Inside-Outside Circle; (12) Bamboo Dance; (13) Jigsaw; (14) Paired Story Telling (Huda, 2011; Slavin, 2014).

Cooperative learning with make a match technique is an active, effective, and fun learning model that prioritizes cooperation and speed among students to achieve learning objectives so that students are actively involved in participating in learning. This technique can be used in all subjects and for all age levels (Isjoni, 2016; Sani. 2013).

\section{RESEARCH METHOD}

\section{Research procedure.}

This classroom action research procedure is carried out in the form of an iterative cycle that will take place through 2 cycles, where each cycle consists of 2 meetings. At the end of the meeting, it is hoped that the goals that have been set can be achieved, namely increasing student learning outcomes, student activities, and teacher performance. Classroom Action Research consists of the following four steps: 1). Planning, namely formulating problems, determining objectives and research methods, and making action plans. 2). Implementation (acting), namely the implementation of the planning carried out together with observations on the impact of actions, especially changes in group dynamics in learning. 3). Observation, carried out systematically to observe the results or the impact of actions on the teaching and learning process. 4). Reflecting, namely reviewing or considering the results or impacts of the actions taken (Arikunto, 2012).

\section{Research Subject, Place, and Time}

The research subjects were students of Chemistry Class X KI 2 Vocational School 1 Cerme Gresik for the 2019/2020 academic year in September-December 2019, with a total of 34 students with different backgrounds who could be subjected to a treatment (Arikunto, 2012).

\section{Performance Indicator}

Performance indicators are performance formulations that will be used as references or benchmarks in determining the success/effectiveness of research (Suwandi, 2011). The performance indicators in this study are sourced from documentation, observation results, interviews, and tests based on the MCC (Minimum Completeness Criteria) 76. The performance 
indicator is if the understanding of concepts in student learning increases. The increase was seen from the students' conceptual understanding before applying cooperative learning with the low make a match technique and after applying the cooperative model the make a match technique students' understanding of the concept increased. This research will end after $85 \%$ of students have experienced an increase in understanding based on student evaluation test scores. If the minimum completeness limit has been reached, it means that the cycle can be stopped and the research is said to have met the standards that have been determined or set by the researcher. Conversely, if it does not meet the specified standards, the next cycle will continue by correcting the deficiencies in the previous cycle.

\section{Data analysis technique}

\section{a. Student learning outcomes}

Student learning outcomes data in the form of evaluation sheets were analyzed using the formula below.

$$
\mathrm{M}=(\mathrm{f} . \mathrm{x}) / \mathrm{N}
$$

Information:

$\mathrm{M}=$ Mean (the average grade of MCC achievers)

$\mathrm{fx}=$ The total number of students who reach the MCC

$\mathrm{N}=$ Number of students who reach MCC

(Indarti, 2014)

To calculate student learning completeness, the researcher uses a formula.

$\%$ Completeness $=($ Number of students completed $/$ Total number of students $) \times 100 \%$

Then the success criteria are consulted in Table 3 below.

Table 3. Criteria for the level of success (completeness) of student learning

\begin{tabular}{lll}
\hline No & Percentage Range & Information \\
\hline $\mathbf{1}$ & $86 \%-100 \%$ & Very good \\
$\mathbf{2}$ & $76 \%-85 \%$ & Well \\
$\mathbf{3}$ & $60 \%-75 \%$ & Enough \\
$\mathbf{4}$ & $55 \%-59 \%$ & Not enough \\
$\mathbf{5}$ & $<54 \%$ & Very less \\
\hline
\end{tabular}

(Kunandar, 2015)

\section{b. Student activity and teacher performance}

To analyze student activities when participating in learning and the performance of teachers who apply the cooperative model of the make a match technique uses the following formula.

$$
\mathrm{P}=(\mathrm{f} / \mathrm{N}) \times 100 \%
$$

Information:

(Pramonoadi et al., 2020)

$\mathrm{P}=$ Percentage of activity frequency that appears

$\mathrm{f}=$ Number of activities that appear

$\mathrm{N}=$ The total number of activities that appear (Kunandar, 2015) 
The level of activity and the success of the learning implementation is determined by the assessment criteria as shown in Table 2 below.

Table 2. Criteria for Teacher Activities and Performance

\begin{tabular}{lll}
\hline No. & Percentage Range & Information \\
\hline $\mathbf{1}$ & $91 \%-100 \%$ & Very good \\
$\mathbf{2}$ & $71 \%-90 \%$ & Well \\
$\mathbf{3}$ & $61 \%-70 \%$ & Enough \\
$\mathbf{4}$ & $<61 \%$ & Not enough \\
\hline
\end{tabular}

(Kunandar, 2015)

\section{RESULTS AND DISCUSSION}

\section{Student Learning Outcomes}

The results of the evaluation in cycle 1 and cycle 2 in learning using the make a math technique for class X KI 2 Vocational School 1 Cerme Gresik students obtained the results as shown in Table 4 below.

Table 4. Learning Evaluation Results Cycle 1 and Cycle 2

\begin{tabular}{|c|c|c|c|c|c|c|c|}
\hline \multirow{3}{*}{ No } & \multirow{3}{*}{$\begin{array}{l}\text { Student Name } \\
\text { (Initial) }\end{array}$} & \multicolumn{3}{|c|}{ Cycle 1} & \multicolumn{3}{|c|}{ Cycle 2} \\
\hline & & \multirow[b]{2}{*}{ Value } & \multicolumn{2}{|c|}{ Information } & \multirow[b]{2}{*}{ Value } & \multicolumn{2}{|c|}{ Information } \\
\hline & & & Complete & $\begin{array}{c}\text { Not } \\
\text { Complete }\end{array}$ & & Complete & $\begin{array}{c}\text { Not } \\
\text { Complete }\end{array}$ \\
\hline 1 & E A P & 52 & & $\sqrt{ }$ & 64 & & $\sqrt{ }$ \\
\hline 2 & F A V & 100 & $\sqrt{ }$ & & 96 & $\sqrt{ }$ & \\
\hline 3 & F D M & 70 & & $\sqrt{ }$ & 76 & $\sqrt{ }$ & \\
\hline 4 & F J A & 65 & & $\sqrt{ }$ & 80 & $\sqrt{ }$ & \\
\hline 5 & FH R & 60 & & $\sqrt{ }$ & 80 & $\sqrt{ }$ & \\
\hline 6 & GP & 90 & $\sqrt{ }$ & & 82 & $\sqrt{ }$ & \\
\hline 7 & GF A & 68 & & $\sqrt{ }$ & 88 & $\sqrt{ }$ & \\
\hline 8 & H D F & 60 & & $\sqrt{ }$ & 88 & $\sqrt{ }$ & \\
\hline 9 & H D P & 76 & $\sqrt{ }$ & & 72 & & $\sqrt{ }$ \\
\hline 10 & $\mathrm{H} \mathrm{S}$ & 74 & & $\sqrt{ }$ & 92 & $\sqrt{ }$ & \\
\hline 11 & H F N & 78 & $\sqrt{ }$ & & 80 & $\sqrt{ }$ & \\
\hline 12 & $\mathrm{HH}$ & 76 & $\sqrt{ }$ & & 88 & $\sqrt{ }$ & \\
\hline 13 & I PS & 88 & $\sqrt{ }$ & & 88 & $\sqrt{ }$ & \\
\hline 14 & I R W & 88 & $\sqrt{ }$ & & 92 & $\sqrt{ }$ & \\
\hline 15 & I S R & 92 & $\sqrt{ }$ & & 100 & $\sqrt{ }$ & \\
\hline 16 & I L F & 76 & $\sqrt{ }$ & & 88 & $\sqrt{ }$ & \\
\hline 17 & I A & 80 & $\sqrt{ }$ & & 88 & $\sqrt{ }$ & \\
\hline 18 & JYP & 80 & $\sqrt{ }$ & & 84 & $\sqrt{ }$ & \\
\hline 19 & KS & 80 & $\sqrt{ }$ & & 84 & $\sqrt{ }$ & \\
\hline 20 & K L K & 85 & $\sqrt{ }$ & & 88 & $\sqrt{ }$ & \\
\hline 21 & K A & 60 & & $\sqrt{ }$ & 88 & $\sqrt{ }$ & \\
\hline 22 & M & 84 & $\sqrt{ }$ & & 92 & $\sqrt{ }$ & \\
\hline 23 & M P K & 78 & $\sqrt{ }$ & & 88 & $\sqrt{ }$ & \\
\hline 24 & M A M & 95 & $\sqrt{ }$ & & 84 & $\sqrt{ }$ & \\
\hline 25 & M L C & 90 & $\sqrt{ }$ & & 92 & $\sqrt{ }$ & \\
\hline 26 & M D S & 88 & $\sqrt{ }$ & & 88 & $\sqrt{ }$ & \\
\hline 27 & M R A & 88 & $\sqrt{ }$ & & 88 & $\sqrt{ }$ & \\
\hline 28 & $\mathrm{M} W \mathrm{~W}$ & 78 & $\sqrt{ }$ & & 84 & $\sqrt{ }$ & \\
\hline 29 & M A Z & 78 & $\sqrt{ }$ & & 92 & $\sqrt{ }$ & \\
\hline 30 & M A Y & 85 & $\sqrt{ }$ & & 88 & $\sqrt{ }$ & \\
\hline 31 & $M A F$ & 65 & & $\sqrt{ }$ & 68 & & $\sqrt{ }$ \\
\hline 32 & $M E N A$ & 95 & $\sqrt{ }$ & & 96 & $\sqrt{ }$ & \\
\hline 33 & M R A & 85 & $\sqrt{ }$ & & 100 & $\sqrt{ }$ & \\
\hline 34 & M R B I & 85 & $\sqrt{ }$ & & 92 & $\sqrt{ }$ & \\
\hline
\end{tabular}




\begin{tabular}{|c|c|c|}
\hline Sum of value & 2692 & \\
\hline Average & 79 & \\
\hline $\begin{array}{l}\text { Classical } \\
\text { completeness }\end{array}$ & $74 \%$ & \\
\hline Lowest Value & 52 & 64 \\
\hline The highest score & 100 & 100 \\
\hline Average Value & 79 & 84 \\
\hline $\begin{array}{l}\text { Students finish } \\
\text { studying }\end{array}$ & 26 students $(73 \%)$ & 31 students $(91 \%)$ \\
\hline $\begin{array}{l}\text { Students do not } \\
\text { finish studying }\end{array}$ & 9 students $(27 \%)$ & 3 students $(9 \%)$ \\
\hline
\end{tabular}

From the recapitulation data on the value of understanding the concept of Chemical Properties, it can be seen that in cycle 1, the value of students' conceptual understanding in the Basic Chemical Analysis subject is still not good, because there are still some students who do not meet the Minimum Completeness Criteria (MCC) of 76. Based on the data above, students who scored below 76 (MCC) were 8 students or $24 \%$, and students who scored above MCC were 26 students or $76 \%$.

Based on the results of the analysis and reflection above, the actions taken in the first cycle have not reached the expected success indicators, this research is said to be successful if the success indicators for student achievement reach $85 \%$, but the results obtained have not achieved maximum results because there are still students whose grades are at under MCC and there are still shortcomings in the implementation of cycle 1, it is necessary to continue improvements in the research cycle 2 (Ariyanti et al, 2013).

From these data, it can be seen that in cycle 2, the value of students' understanding of concepts in Basic Chemistry Analysis material is very good, because only 3 students out of 34 students have not met the Minimum Graduation Criteria (MCC) of 76. In cycle 2, students are already familiar with the model. cooperative learning makes a match and students already understand the material Properties of Chemicals. From the recapitulation data on the understanding value of cycle 2, students who scored below 76 (MCC) were 3 students or 9\% and students who scored above MCC were 31 students or $91 \%$, it can be said that learning Basic Chemical Analysis through the application of the cooperative model of the make a match technique in cycle 2 has been successful because it has achieved the target performance indicator of achievement (Kristiawan, 2013). Thus, researchers do not need to continue research in the next cycle. It can be concluded that the research carried out for two cycles with four meetings succeeded in improving student learning outcomes.

\section{Observation of Student Learning Activities}

This observation activity is carried out during the learning process. Observation is done by observing the activities of teachers and students. This observation was carried out to obtain data regarding the suitability of the implementation of learning and student activities during the learning process. In this observation, the researcher collaborated with other teachers who acted as observers and colleagues to document the learning. Observations are not only focused on student activities, but are also carried out on teacher activities during learning so that observations are carried out thoroughly on all aspects, both from aspects of student activities and teacher performance (Primarinda et al, 2012). A description of the observations that have been carried out during learning in cycle 1 and cycle 2 is presented in Table 5 below. 
Table 5. Observation of student activities in cycle 1 and cycle 2

\begin{tabular}{|c|c|c|c|c|c|c|c|}
\hline \multirow[b]{2}{*}{ No } & \multirow[b]{2}{*}{$\begin{array}{c}\text { Form of student } \\
\text { activity }\end{array}$} & \multicolumn{3}{|c|}{ Cycle 1} & \multicolumn{3}{|c|}{ Cycle 2} \\
\hline & & $\begin{array}{l}\text { Sum of } \\
\text { students }\end{array}$ & Percentage & Information & $\begin{array}{l}\text { Sum of } \\
\text { students }\end{array}$ & Percentage & Information \\
\hline 1 & $\begin{array}{l}\text { Answering } \\
\text { questions during } \\
\text { apperception }\end{array}$ & 18 & $53 \%$ & Not good & 24 & $71 \%$ & good \\
\hline 2 & $\begin{array}{l}\text { Pay attention to the } \\
\text { teacher's lessons } \\
\text { and instructions }\end{array}$ & 22 & $65 \%$ & good & 30 & $88 \%$ & good \\
\hline 3 & $\begin{array}{l}\text { Collaboration } \\
\text { between students } \\
\text { in groups }\end{array}$ & 21 & $62 \%$ & good & 28 & $82 \%$ & good \\
\hline 4 & $\begin{array}{l}\text { The activity of } \\
\text { conducting } \\
\text { experiments } \\
\text { observing chemical } \\
\text { label packaging }\end{array}$ & 24 & $71 \%$ & good & 24 & $71 \%$ & good \\
\hline 5 & $\begin{array}{l}\text { Ability to express } \\
\text { opinions in good } \\
\text { language }\end{array}$ & 21 & $62 \%$ & good & 24 & $71 \%$ & good \\
\hline 6 & $\begin{array}{l}\text { Find a partner on } \\
\text { time }\end{array}$ & 20 & $59 \%$ & Not good & 20 & $60 \%$ & good \\
\hline 7 & $\begin{array}{l}\text { Presenting a } \\
\text { presentation with a } \\
\text { partner }\end{array}$ & 24 & $71 \%$ & good & 24 & $71 \%$ & good \\
\hline 8 & $\begin{array}{l}\text { Q\&A discussions- } \\
\text { presentations }\end{array}$ & 22 & $65 \%$ & good & 26 & $76 \%$ & good \\
\hline 9 & $\begin{array}{l}\text { Doing evaluation } \\
\text { questions with tips }\end{array}$ & 25 & $74 \%$ & good & 32 & $94 \%$ & Very good \\
\hline 10 & $\begin{array}{l}\text { Work on } \\
\text { evaluation } \\
\text { questions on time }\end{array}$ & 26 & $76 \%$ & good & 30 & $88 \%$ & good \\
\hline $\begin{array}{l}\text { Perce } \\
\text { Perce } \\
\text { Perce }\end{array}$ & $\begin{array}{l}\text { ntage }<60 \% \\
\text { ntage } 60 \%-90 \% \\
\text { ntage }>90\end{array}$ & $\begin{array}{l}\text { ot good } \\
\text { ood } \\
\text { ery good }\end{array}$ & & & & & \\
\hline
\end{tabular}

The results of observations in Table 5 regarding student activities/activities in learning Basic Chemical Analysis of Material Properties of Chemicals in cycle 1 for 2 meetings by applying a cooperative model of make a match technique can be obtained an overview of student activities in learning as follows. a) The willingness of students to learn has shown an increase. This can be seen from the students who are willing to answer questions during the apperception. b) The attention of some students is quite good in paying attention to the lessons delivered by the teacher, but still needs to be improved. c) Some students are enthusiastic and happy in participating in learning using the make a match cooperative learning model, this is shown by the cooperation between students which has slightly increased. However, there are also those who are less enthusiastic about participating in learning (Bubin, 2012). d) The activeness of students in participating in learning is still low, this is evident when the teacher offers students to conduct experiments observing the packaging of chemical labels, there are still many embarrassed students. e) Some students still talk alone with their friends and disturb their friends. f) Some students can do the evaluation questions well and on time.

In cycle 1 it can be concluded that student learning activities are quite good, but teachers need to motivate to increase student learning activities so that the results obtained by students 
increase. Therefore, it is necessary to make improvements in learning activities by actively involving students through the application of a cooperative model of make a match technique.

The results of details regarding student activities in learning Basic Chemical Analysis of Material Properties of Chemicals in cycle 2 for 2 meetings, by applying a cooperative model of make a match technique can be obtained an overview of student activities in learning as follows. a) Most students listen and pay attention to the teacher's explanation seriously. b) Most students are enthusiastic and happy in participating in learning by using the make a match cooperative learning model. c) Student cooperation in participating in learning has increased, this is evident when applying the make a match cooperative learning model, many students are active and not shy when looking for make a match cards and pairs they get. d) The effectiveness of the application of the cooperative model of the make a match technique is optimal because many students are actively participating in learning and are not shy when they come forward to read question cards and answer cards with their friends. e) Most students can do the evaluation questions well and on time. Overall, based on the results of observations of students' activities in learning Basic Chemical Analysis of Chemical Properties by applying a cooperative model of make a match technique in cycle 1 to cycle 2, it can be concluded that students' attention, activity, and enthusiasm for learning have increased.

\section{Teacher Performance Observation Results}

In this study, the researcher acts as a teacher and collaborates with lecturers from 2 state universities as observers to observe the learning process and discussion partners in reflection. The results of the observations in cycle 1 and cycle 2 are shown in Table 5 below.

Table 5. Teacher Performance Observation Data Cycle 1 and Cycle 2

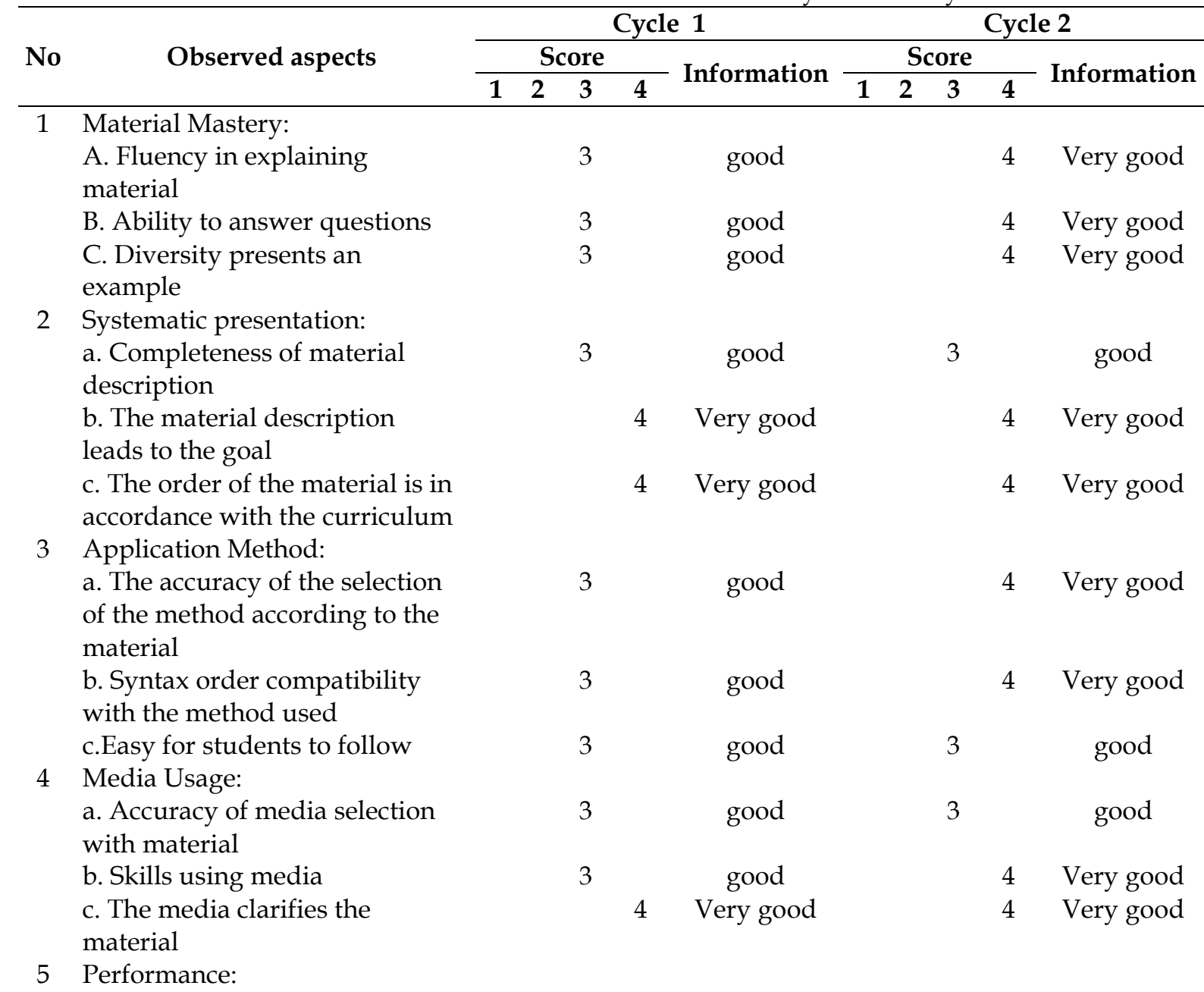




\begin{tabular}{|c|c|c|c|c|c|c|c|}
\hline & a. Clarity of spoken voice & & 4 & Very good & & 4 & Very good \\
\hline & $\begin{array}{l}\text { b. Communicating between } \\
\text { teachers and students }\end{array}$ & 3 & & good & & 4 & Very good \\
\hline & $\begin{array}{l}\text { c. The flexibility of the teacher's } \\
\text { attitude with students }\end{array}$ & 3 & & good & & 4 & Very good \\
\hline \multirow[t]{4}{*}{6} & Giving Motivation: & & & & & & \\
\hline & $\begin{array}{l}\text { a. Teacher enthusiasm in } \\
\text { teaching }\end{array}$ & 3 & & good & & 4 & Very good \\
\hline & $\begin{array}{l}\text { b. The teacher's concern for } \\
\text { students }\end{array}$ & 3 & & good & & 4 & Very good \\
\hline & $\begin{array}{l}\text { c. Accuracy of reward and } \\
\text { punishment }\end{array}$ & 3 & & good & 3 & & good \\
\hline \multirow[t]{6}{*}{7} & Evaluation and Closing & & & & & & \\
\hline & $\begin{array}{l}\text { a. Appropriateness of the } \\
\text { number of questions and time }\end{array}$ & 3 & & good & & 4 & Very good \\
\hline & b. Order of evaluation & & 4 & Very good & & 4 & Very good \\
\hline & c. Final conclusion of learning & 3 & & good & 3 & & good \\
\hline & $\begin{array}{l}\text { d. Assignment for the next } \\
\text { meeting }\end{array}$ & 3 & & good & 3 & & good \\
\hline & Score & 51 & 20 & & 18 & 64 & \\
\hline \multicolumn{2}{|c|}{ Total score } & & 71 & & & 82 & \\
\hline \multicolumn{2}{|c|}{ Maximum score } & & 88 & & & 88 & \\
\hline \multicolumn{2}{|r|}{ Percentage $=(78 / 88) \times 100 \%=89 \%$} & & $81 \%$ & & & $93 \%$ & \\
\hline \multirow{2}{*}{\multicolumn{8}{|c|}{$\begin{array}{l}4=\text { very good } \\
3=\text { good }\end{array}$}} \\
\hline \multirow{2}{*}{\multicolumn{2}{|c|}{$\begin{array}{l}3=\text { good } \\
2=\text { not good }\end{array}$}} & & & & & & \\
\hline & not good & & & & & & \\
\hline \multicolumn{8}{|c|}{$1=$ very not good } \\
\hline
\end{tabular}

Observation of teacher performance in learning cycle 1 was carried out for 2 meetings. Based on the observations of the teacher's performance in making the Learning Implementation Plan and the implementation of learning in cycle 1 was good. However, it is necessary to make improvements in teaching so that there is a significant increase (Riski, 2012).

These problems include: 1) The teacher is not able to condition the class so that there are still busy students in the class, and there are still some students who are passive towards the lesson. 2) The teacher in guiding and explaining to the students about the application of the make a match model is still unclear. 3) During the cooperative learning of the make a match technique, there were still some students who did not want to pair the question and answer cards. 4) There are still some students who are shy when paired with male and female friends. 5) At the time of taking the cards students should be left to take them alone, so that students are more interested in the cards they get and are challenged to pair them. So learning is more fun. (Dwikoranto, 2020). Based on the problems above, it can be reflected that the learning of Basic Chemical Analysis of the Material Properties of Chemicals by applying the cooperative model of the make a match technique is still not optimal (Kristiawan, 2013). So researchers must find solutions to overcome problems that hinder the smooth process of learning Basic Chemical Analysis of Chemical Properties by applying a cooperative model of make a match technique.

Things that can be done are as follows. 1) The attention of the teacher in the classroom must be spread out so that students can listen to the teacher's explanation well and actively participate in learning. 2) The teacher provides an explanation of the steps for using the cooperative model of the make a match technique clearly and the teacher gives an overview of its use so that students are not confused. 3) During cooperative learning the make a match technique takes place, the teacher observes students one by one so that students are not busy themselves in looking for their partner cards. The teacher also always provides guidance to all students so that they want to work together with their friends, so that the results obtained can 
be maximized. 4) The teacher gives direction so that students who get a male and female partner so that they are not ashamed and continue to carry out learning activities well. 5) Students who will get cards are given the freedom to take cards so that students are more interested in learning because learning to make a match is very interesting. In addition, the teacher also guides and observes each student to pair the cards he gets, the teacher also guides each pair of cards to convey the questions he has obtained.

Cycle Action 2. a) The teacher has prepared and implemented the Learning Implementation Plan properly. b) The formulation of learning objectives/basic competencies is clear. c) The development of materials, learning media, learning resources, and the making of match cards are good. d) The teacher has opened the lesson, gave an introduction, and asked questions about the material being taught in order to improve student activity very well. e) The teacher's attention is evenly distributed to all students. f) The teacher provides guidance to all students to find pairs of make match cards. g) The teacher gives a firm warning to students who pay less attention to the lesson. h) In the closing activity, the teacher has reflected and followed up on the learning that has been carried out well (Harnoto et al, 2021). Based on the observations of the teacher's performance in making the Learning Implementation Plan and the implementation of learning in cycle 2 , it has increased from cycle 1.

\section{CONCLUSION}

Based on the results of classroom action research carried out in two cycles, using the cooperative learning model of make a match technique in chemistry subjects for students of Class X KI 2 SMKN 1 Cerme Gresik, it can be concluded that the application of the cooperative learning model of the make a match technique can improve learning outcomes. This is evident in the average grade before the action was taken of 70 . Students who scored above or equal to the MCC (76) were 16 students (47\%) with the highest score of 92 and students who scored below the MCC were 18 students ( $53 \%$ ) with the lowest score of 40 . After taking action in cycle 1 the average grade of 79 . Students who scored above or equal to the MCC were 26 students (76\%) with the highest score of 100 and students who scored below the MCC as many as 8 students $(24 \%)$ with the lowest score of 52 . Cycle 2 the average grade of 84 . Students who scored above the MCC (completed learning) were 31 students (91\%) with the highest score of 100, while students who scored below the MCC (did not complete learning) as many as 3 students $(9 \%)$ with the lowest score of 64 . The students' attention, activity, and enthusiasm for learning increased. Teacher performance in learning has increased. This research can be used limited to subjects with similar characteristics, then it can be tested on other subjects.

\section{REFERENCES}

Ardana, I. K., Arnyana, I. B. P., \& Setiawan, I. G. A. N. (2013). Studi komparatif penerapan model pembelajaran berbasis masalah dan model pembelajaran kooperatif tipe STAD terhadap keterampilan berpikir kritis dan kinerja ilmiah biologi SMA. Jurnal Pendidikan dan Pembelajaran IPA Indonesia, 3 (1).

Arends, R. I. (2018). Learning To Teach Belajar Untuk Mengajar. Pustaka Pelajar.

Arikunto, S. (2012). Prosedur penelitian suatu pendekatan praktik. Rineka Cipta.

Ariyanti, N. W. P., Lasmawan, I. W., \& Dantes, N. (2013). Pengaruh model pembelajaran kooperatif tipe jigsaw terhadap kemampuan berpikir kritis dan prestasi belajar siswa dalam pembelajaran IPS pada siswa kelas IV SD cipta dharma Denpasar. Pendasi: Jurnal Pendidikan Dasar Indonesia, 3(1).

Harnoto, B. T., Setiani, R., Widuroyekti, B., Sambada, D., Dwikoranto, Lindsay, N., Bergsma. (2021). The implementation of the quantum teaching strategy with multiple intelligence approach at state senior high school. IJORER: International Journal of Recent Educational Research, 2(1), 73-85. https://doi.org/10.46245 /ijorer.v2i1.78 
Bubin. (2012). Meningkatkan kemampuan pemecahan masalah matematik peserta didik melalui penggunaan model pembelajaran kooperatif tipe think pair share. http://journal.unsil.ac.id/jurnalunsil-197-.html.

Dimyati \& Mudjiono. (2016). Belajar dan Pembelajaran. PT Rineke Cipta.

Direktorat Sekolah Menengah Kejuruan Direktorat Jendral Pendidikan Vokasi. (2018). Kompetensi inti dan kompetensi dasar mata pelajaran SMK. Standar No. 464/D.D5/KR/2018. Kementerian Pendidikan dan Kebudayaan.

Dwikoranto, Setiani, R., Widuroyekti B., Tresnaningsih, S., Sambada, D., Setyowati, T., Rohman, A., Harnoto, B. T. (2020). The effectiveness of the Student Activity Sheet (SAS) on TeachingLearning and Creativity (TLC) model to increase creativity competence. Studies in Learning and Teaching, 1(3), 175-184. https://doi.org/10.46627/silet.v1i3.36

Huda, M. (2011). Cooperatif learning. Pustaka Belajar.

Indarti, T. (2008). Penelitian Tindakan Kelas (PTK) dan penulisan ilmiah. FPBS Unesa.

Isjoni, A. M. (2016). Pembelajaran kooperatif meningkatkan kecerdasan komunikasi antar peserta didik. Pustaka Pelajar.

Kristiawan, M. (2013). The Implementation of cooperative learning in english class of favorite school of secondary high school 5 Batusangkar, West Sumatera. International Journal of Educational Administration and Policy Studies, 5(6), 85-90.

Kunandar. (2015). Penilaian autentik suatu pendekatan praktis. PT Raja Grafindo Persada.

Lie, A. (2015). Cooperative learning mempraktikkan cooperative learning di ruangruang kelas. PT. Grasindo Widia Sarana Indonesia.

Pramonoadi, Tresnaningsih, S., Faqih, A., Setiani, R., Dwikoranto. (2020). The validity of concept attainment with multi representation as an alternative learning model to improve students' mastery of concepts and scientific consistency. Studies in Learning and Teaching, 1(2), 122-132. https:// doi.org/10.46627/silet.v1i2.35

Primarinda, I., Maridi, \& Marjono. (2012). Pengaruh model pembelajaran cooperative learning tipe Group Investigation (GI) terhadap keterampilan proses sains dan hasil belajar biologi siswa kelas X SMA Negeri 4 Surakarta tahun pelajaran 2011/2012. Jurnal Pendidikan Biologi FKIP UNS, 4(2) 60-71.

Riski, Y. E. (2012). Pengaruh penerapan model pembelajaran kooperatif tipe think-pair-share terhadap kemampuan komunikasi matematis siswa. Jurnal Pendidikan Matematika Unila, $1(1)$.

Rusman. (2016). Model-model pembelajaran mengembangkan profesional guru. Raja Grafindo Persada.

Sani, R. A. (2013). Inovasi pemelajaran. PT Bumi Aksara.

Slavin, R. E. (2014). Cooperatiflearning. Nusa Media.

Sudjana, N. (2016). Penilaian hasil proses belajar mengajar. PT Remaja Rosdakarya.

Sugiyanto. (2018). Model-model pembelajaran inovatif. Yunus Pustaka.

Suwandi, S. (2011). Penelitian Tindakan Kelas (PTK) dan penulisan karya tulis ilmiah. Yuma Pustaka.

Slavin, R. E. (2013). Instruction based on cooperative learning. In R. E. Mayer, \& P. A. Alexander (Eds.), Handbook of Research on Learning and Instruction (pp. 344-360). Taylor and Francis Group.

Setyowati T., Setiani R., Sambada D., Surasmi, W. A., Dwikoranto. (2020). Improving the quality of tutorials to create a quality culture through an integrative selection of tutors. Studies in Philosophy of Science and Education, 1(2), 1-3. https:// doi.org/10.46627/sipose.v1i3.51

Trianto. (2011). Pebelajaran inovatif terpadu konsep strategi implementasinya dalam kurikulum tingkat satuan pendidikan. Bumi Aksara. 
Make A Match Techniques in Cooperative Learning: Innovations to Improve Student Learning Outcomes, Student Learning Activities, and Teacher Performance

https://doi.org/10.46627/silet.v2i2.74

Author (s):

Viyayanti

SMK Negeri 1 Cerme Gresik,

Jl. Jurit Cerme Gresik 61171, Indonesia

Email: viyayanti.smkncerme@gmail.com

* Dwikoranto (Corresponding Author)

Department of Physics, Faculty of Mathematics and Natural Science,

Universitas Negeri Surabaya,

Jl. Ketintang, Surabaya 60231, Indonesia

Email: dwikoranto@unesa.ac.id 